\title{
ACTION SPECTRUM OF Baculovirus spodoptera ON LEPIDOPTERA PESTS
}

\section{CAMILA DA SILVA FERNANDES SOUZA ${ }^{1}$, FERNANDO HERCOS VALICENTE ${ }^{2}$, MARCOS ANTÔNIO MATIELLO FADINI ${ }^{3}$ and RICARDO ANTÔNIO POLANCZYK ${ }^{4}$}

\author{
${ }^{1}$ Universidade Federal de Lavras, camilasfs4@hotmail.com; \\ ${ }^{2}$ Embrapa Milho e Sorgo,fernando.valicente@embrapa.br; \\ ${ }^{3}$ Universidade Federalde São JoãoDel Rei, camilasfs4@hotmail.com; fadini@ufsj.edu.br; \\ ${ }^{4}$ UniversidadeEstadualPaulista “JuliadeMesquitaFilho”,FaculdadedeCiênciasAgrágriaseVeterinárias,rapolanc@yahoo.com.br;
}

Revista Brasileira de Milho e Sorgo, v.16, n.1, p. 52-60, 2017

\begin{abstract}
This work evaluated the spectrum of action of Baculovirus spodoptera (SfMNVP) - 6NR on the fall armyworm Spodoptera frugiperda, corn earworm Helicoverpa zea and the sugar cane borer Diatraea saccharalis, species of economic importance in maize. For the bioassays, corn leaves immersed in a baculovirus suspension were used for baculovirus inoculation in fall armyworm and earworm and pieces of sugar cane for the corn borer. The foods were immersed in viral solutions of different baculovirus concentrations determined in a Neubauer chamber. The control only distilled water was used instead of the baculovirus suspension. The larvae fed for 48 hours and were then transferred to an artificial diet, without the baculovirus. After evaluating mortality, the development of the offspring (F1) was accompanied, evaluating the parameters: mortality, pupation and the number of egg masses in the first generation. The baculovirus was specific to fall armyworm and innocuous to earworm and the corn borer in the first generation. In the second generation, baculovirus was innocuous for all three species. The percentage of pupation showed an inverse relation with mortality for the three species in two generations. The number of egg masses in F1 was lower in S. frugiperda, did not change for D. saccharalis and higher in H. zea.
\end{abstract}

Keywords: Helicoverpa zea, Spodoptera frugiperda, Diatraea saccharalis, entomopathogenie virus.

\section{ESPECTRO DE AÇÃO DE Baculovirus spodoptera A LEPIDÓPTEROS PRAGA}

RESUMO - Neste trabalho foi avaliado o espectro de ação do Baculovirus spodoptera (SfMNVP) - 6NR à lagartado-cartucho Spodoptera frugiperda, à lagarta-da-espiga Helicoverpa zea e à broca-da-milho Diatraea saccharalis, espécies de importância econômica na cultura do milho. Para a realização dos bioensaios foram utilizadas folhas de milho imersas em suspensão com o baculovírus em concentrações determinadas em câmara de Neubauer, para lagartado-cartucho e para lagarta-da-espiga. Para broca-do-milho o substrato utilizado foi colmo de cana-de-açúcar. Na testemunha foi utilizada somente água destilada ao invés da suspensão com o baculovírus. As lagartas se alimentaram por 48 horas, após este período, foram transferidas para dieta artificial sem o bacilovírus. Após a avaliação da mortalidade, o desenvolvimento da prole (F1) foi acompanhado sendo avaliados os parâmetros: mortalidade, pupação e o número de massas de ovos na primeira geração. O baculovírus foi especifico para lagarta-do-cartucho e inócuo tanto para lagartada-espiga quanto para broca-do-milho na primeira geração. Na segunda geração, o baculovírus foi inócuo para as três espécies. A porcentagem de pupação apresentou relação inversa com a mortalidade para as três espécies nas duas gerações. O número de massas de ovos na F1 foi menor em $S$. frugiperda, não alterado para $D$. saccharalis e maior em $H$. zea. Palavras-chave: Helicoverpa zea, Spodoptera frugiperda, Diatraea saccharalis, vírus entomopatogênico. 
Among the entomopathogenic agents, the baculovirus has shown promise in controlling agricultural pests due to its efficiency and selectivity to natural enemies (Barreto, 2005). The baculoviruses (Baculoviridae) of genera Nucleopolyhedrovirus (NPV) and Granulovirus (Gv) act in the midgut of insects (Valicente \& Tuelher, 2009). For the virus to be lethal to insects, it is necessary that the insect midgut is alkaline. Under these conditions the viral inclusion bodies are dissolved, releasing the virions (= nucleocapsid plus the envelope). When the baculoviruses reach the hemolymph and the insect tracheal system they spread and provoke infections, causing cell membrane disruption. In this process, the insects lose the ability to feed and move about and there is body discoloration. The multiplication and spread of these viruses is very efficient and quick in nature which enhances the natural microbiological control of larvae in the field (Andrade et al., 2004).

The fall armyworm, Spodoptera frugiperda, of utmost importance in corn in Brazil (Figueiredo et al., 2006) is quite sensitive to baculoviruses (Valicente $\&$ Tuelher, 2009) and at the same time the virus is selective to natural enemies, chacteristics that make its use an advantageous tactic (Barreto et al., 2005). The corn earworm, Helicoverpa zea considered a key pest in the United States, causes direct and indirect damage in corn (Luiz \& Magro, 2007), while the sugarcane borer Diatraea saccharalis is also a very important pest in corn by attacking the stem.

Control of corn larvae is commonly done with organo-synthetic insecticides, which can negatively impact the agro-ecosystem (Santos et al., 2007). Because of these negative effects alternative means, such as biological control, are sought. Thus, there has been successful use of entomopathogenic agents such as viruses, fungi, nematodes or bacteria (Oliveira et al., 2006). However, the specificity is one of the main disadvantages of the virus, although there are certain broad spectrum viruses, such as the baculovirus Autografa californica, Anagrafa falcifera and Mamestra brassicae (OECD, 2002) and more recently there has been the use of the Helicoverpa zea virus to control Helicoverpa armigera in Brazil. Thus, the aim of this study was to evaluate the range of action of Baculovirus spodoptera (SfMNVP) - 6NR in S. frugiperda, H. zea and D. saccharalis larvae.

\section{Material and Methods}

The experiment was conducted in the biological control laboratory of Embrapa Milho e Sorgo- MG. The baculovirus used was isolate 6NR, taken from Spodoptera frugiperda, which has the characteristic of not rupturing the seed coat after the death of the larvae (Vieira et al., 2012). The baculovirus was purified on sucrose gradient to increase its purity according to the method described by Yamamoto \& Tanada (1978).

The caterpiller species evaluated were Spodoptera frugiperda, Helicoverpa zea and Diatraea saccharalis, raised in $50 \mathrm{ml}$ cups with an acrylic cover. The D. saccharalis caterpillers were placed in petri dishes and fed with an artificial diet from hatching until pupation. After emergence, the adults were housed in PVC cages containing paper, serving as a substrate for oviposition. As food, a sugar solution was used (sugar and ascorbic acid), with the exception of for D. saccharalis. The larvae were conditioned in a room at a $25.0 \pm 11^{\circ} \mathrm{C}, 50.0 \pm 10 \% \mathrm{RH}$ and 8 hours of photoperiod, where they were also accomodated during the experiment. For $S$. frugiperda we used an 
artificial diet recommended by Parra (1996), for $H$. zea a artificial diet was used modified by Greene et al. (1976) and for D. saccharalis we used the Hensley \& Hammond (1968) modified artificial diet.

Before inoculation of the baculovirus a count of polyhedron $/ \mathrm{ml}$ was taken in five dilutions: $-10^{-5}, 10^{-4}, 10^{-3}, 10^{-2}, 10^{-1}$ plus the control using $10 \mathrm{ml}$ per concentration. For the inoculation two drops of detergent "Tween" 20 was added for every $10 \mathrm{ml}$ as adhesive sulfactant for better dispersion of the viral solution onto the leaves.

The dilution was serialized 1 to 9 , every $9 \mathrm{ml}$ of water, $1 \mathrm{ml}$ of virus. The polyhedra count was performed in a 40x optical microscope in Phase 2 through a Neubauer chamber, using 10 microliters of the solution in each side of the chamber. The concentrations of viable polyhedra/ml used in the inoculation in $S$. frugiperda were $5.0 \times 10^{4} ; 2.0 \times 10^{5}$; $2.4 \times 10^{6} ; 1.77 \times 10^{7}$ and $1.8 \times 10^{8}$ polyhedra $/ \mathrm{ml}$. The baculovirus concentrations evaluated for $H$. zea, were $5.0 \times 10^{4} ; 1.0 \times 10^{5} ; 1.25 \times 10^{6} ; 1.33 \times 10^{7} ; 1.8 \times$ $10^{8}$ polyhedra $/ \mathrm{ml}$. The polyhedra $/ \mathrm{ml}$ concentrations obtained for inoculation of $D$. saccharalis were 5.0 $\mathrm{x} 10^{4} ; 2.0 \times 10^{5} ; 2.4 \times 10^{6} ; 1.22 \times 10^{7}$ and $1.26 \times 10^{8}$ polyhedra / $\mathrm{ml}$.

For inoculation of baculovirus in S. frugiperda and $H$. zea, corn leaves were cut into discs and dipped in a solution with the virus the with evaluated dilutions. After removing excess solution the leaves were transferred to $50 \mathrm{ml}$ cups, which held the stored larvae for six days, one larvae per cup. For the $D$. saccharalis larvae we used pieces of sugarcane, moistened in the viral solution, in the same manner as for the previous two larvae species, and placed in Petri dishes.

Two days after inoculation the larvae were transferred to feed on their specific artificial diet. From the fifth day after inoculation, larvae were evaluated daily for death or escape, until the formation of pupae. The larvae that did not die were monitored until they reached their adult phaseage. Sublethal effects caused by the baculovirus in the second generation progeny were evaluated. Adults were placed in PVC cages lined with foolscap as an environment for egg laying. Larvae were separated regarding diet and container according to each species until the formation of pupae and adults, in order to observe the development of the second generation. The second generation was monitored, as in the previous experiment, in a room with temperature of $25.0 \pm 1^{\circ} \mathrm{C}, 50.0 \pm 10 \% \mathrm{RH}$ and an 8 hour photophase.

We evaluated four groups of 24 larvae contained in plastic cups (S. frugiperda and $H$. $z e a$ ) or Petri dishes (D. saccharalis), totaling four replicates per concentration tested. We used a completely randomized design (CRD) for mounting the experiments. Non-linear models were fitted to the data obtained, the independent variable (x) being the Baculovirus spodoptera polyhedral concentrations (SfMNPV) 6NR and the dependent variables (y) being the mortality rate, pupation percentage and egg mass quantity. The models were evaluated as to distribution of residuals and regarding the significance of the estimated parameters $(\alpha=5 \%)$ (Crawley, 2007). We used the statistical package $\mathrm{R}$ for adjustment and evaluation of non-linear models and residual analysis ( $\mathrm{R}$ Development Core Team, 2011).

\section{Results and Discussion}

Spodoptera frugiperda first generation larvae were highly susceptible to Baculovirus spodoptera $(\mathrm{SfMNPV}) 6 \mathrm{NR}[\mathrm{df}=1$; mortality percent $=89.38$ 
1-exp (concentration $-4.631 * \times 10^{-7}$ )]. As for the fitted model, the polyhedra concentration able to kill $50 \%$ of the $S$. frugiperda population $\left(\mathrm{LC}_{50}\right)$ estimated at $1.77 \times 10^{6}$ polyhedra $/ \mathrm{ml}$. However, B. spodoptera (SfMNPV) 6NR was innocuous to Helicoverpa zea and Diatraea saccharalis.

In an inverse relationship, the pupation percentage of $S$. frugiperda was affected negatively by the baculovirus $[\mathrm{df}=1$; pupation percentage $=$ $90.14 * \exp \left(\right.$ concentration-3.049* $\times 10^{-7}$ )] which was not observed for H. zea and D. saccharalis (Figure 1). This result was a consequence of the higher mortality of individuals. That is, the mortality of individuals necessarily leads to a lower pupation percentage.

In the second generation, different from what was observed in the first, the B. spodoptera

A)

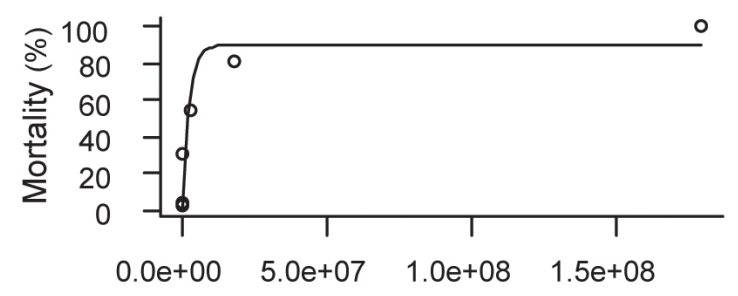

Polyhedra/mL

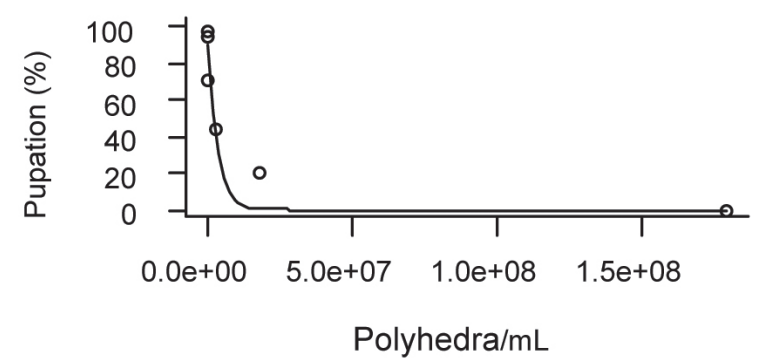

Polyhedra/mL

B)

C)
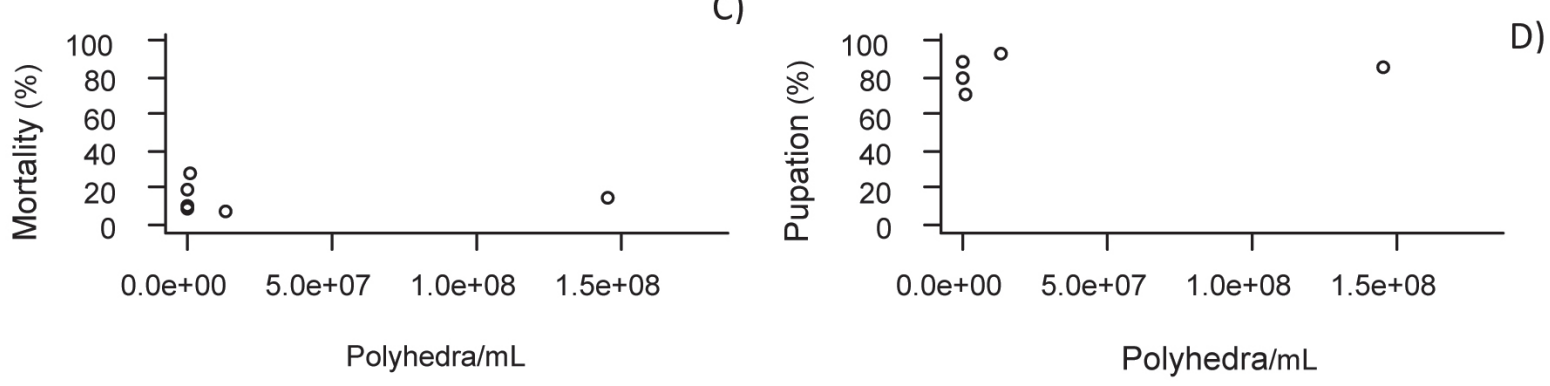

E)

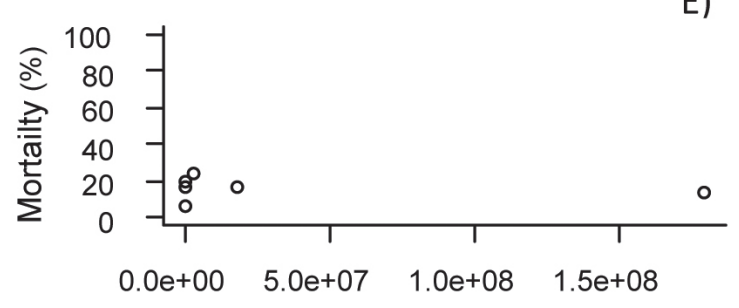

Polyhedra/mL

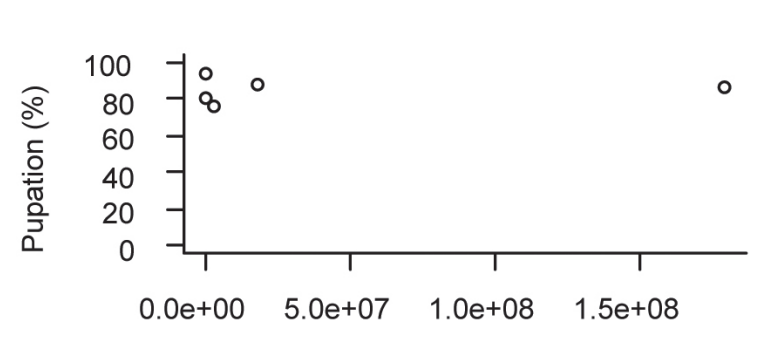

Polyhedra/mL

Figure 1. Mortality and pupation of Spodoptera frugiperda larvae (A and B), Helicoverpa zea (C and D) and Diatraea saccharalis (E and F) in the first generation exposed to Baculovirus spodoptera polyhedra concentrations (SfNPV) 6NR per ml. Sete Lagoas, MG, 2012. 
(SfMNPV) 6NR was innocuous to $S$. frugiperda as well as to $H$. zea and to D. saccharalis. The same was observed for the three species regarding pupation evaluation (Figure 2). This result, as observed in the first generation, was a positive correlation between the number of dead individuals and pupation. The lower the number of larvae killed by $B$. spodoptera
(SfMNPV) 6NR, the greater the chance to develop and move into the pupal stage.

The Baculovirus spodoptera (SfMNPV) 6NR reduced the number of of $S$. frugiperd $a[\mathrm{df}=1$; number of egg masses $=35.90 * \exp ($ concentration $-7.984 *$ $\left.\mathrm{x} 10^{-8}\right)$ ] and did not affect the egg mass quantity of $D$. saccharalis (Figure 3).
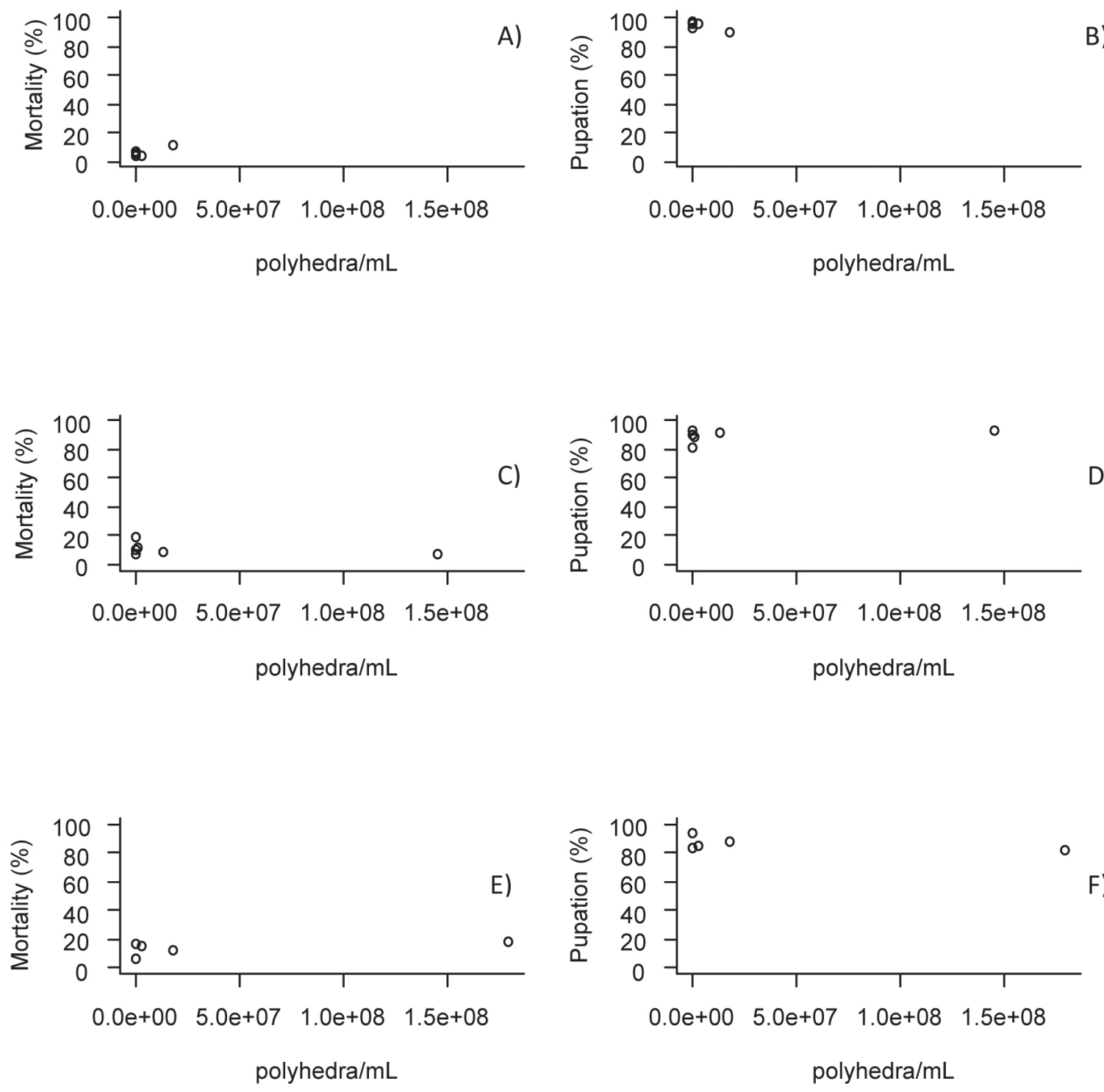

Figure 2. Mortality and pupation of Spodoptera frugiperda larvae (A and B), Helicoverpa zea (C and D) and Diatraea saccharalis (E and F) of the second generation exposed to concentrations of Baculovirus spodoptera polyhedra (SfNPV) 6NR per ml. Sete Lagoas, MG, 2012. 

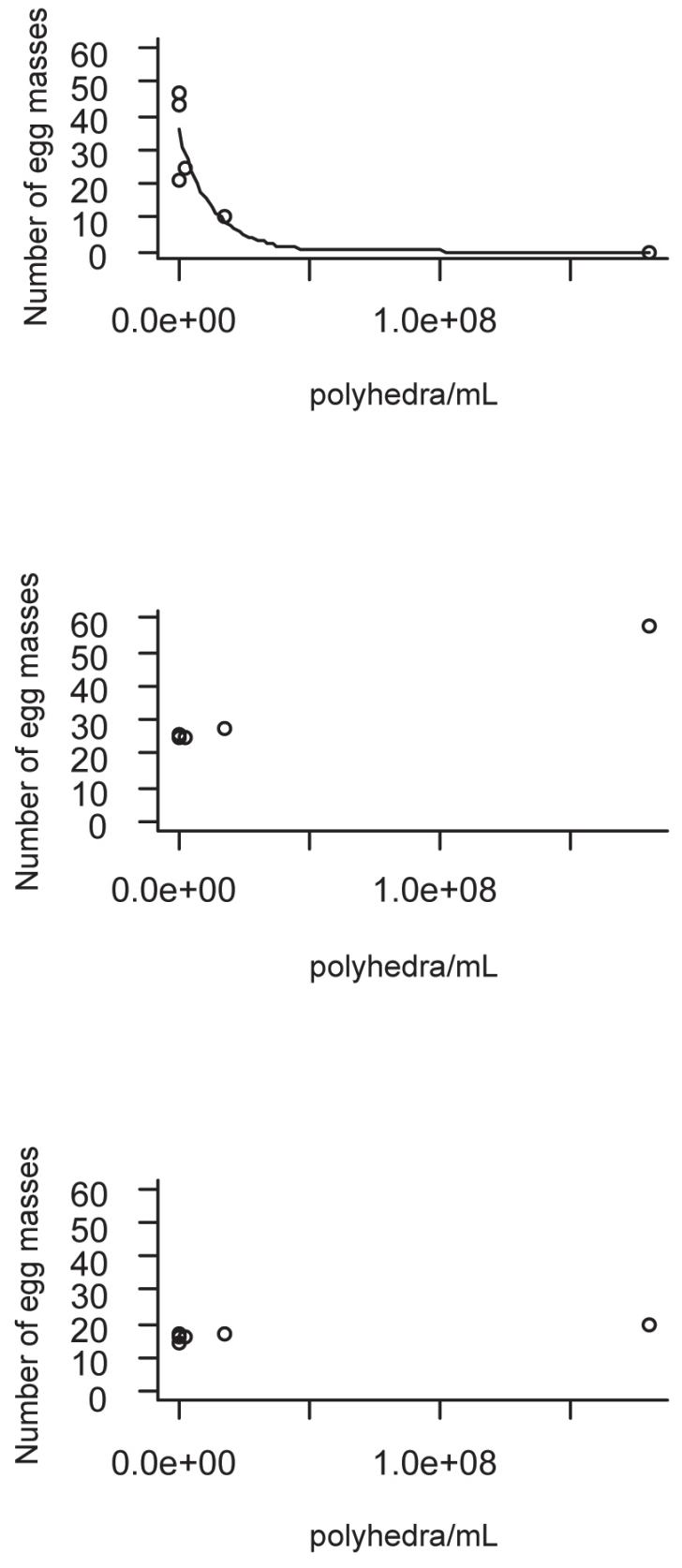

Figure 3. Number of egg masses of Spodoptera frugiperda A), Helicoverpa zea B) and Diatraea saccharalis $\mathrm{C}$ ) of the first generation exposed to Baculovirus spodoptera polyhedra concentrations (SfNPV) 6NR per ml. Sete Lagoas, MG, 2012.
After adjusting the non-linear models, experimental residules were evaluated to measure the adequacy of models. A random distribution was observed, showing that a significant part of the systematic data variation was explained by the adjusted models.

The Baculovirus spodoptera (SfMNPV) $6 \mathrm{NR}$, as well as other baculoviruses isolated from arthropods, was specific to Spodoptera frugiperda. Conversely, as the concentration decreased, the mortality rate also declined, as it is by via contains fewer polyhedra. This information is relevant because it is via the intake of polyhedra that the midgut

B) protein matrix (= midgut) is dissolved, the virions are released and the infective particles penetrate the cells causing the death of the larvae.

Upon death of the species Helicoverpa zea and Diatraea saccharalis there were symptoms characteristic of baculovirus action. The fact that B. spodoptera (SfMNPV) - 6NR was innocuous to $H$. zea and D. saccharalis can be explained by the specificity of the baculovirus action. The infective particles enter the midgut cells through specific receptors. Thus it is hypothesized that $H$. zea and $D$. saccharalis do not possess such specific receptors for infection as does $S$. frugiperda. This may thus explain the harmlessness of B. spodoptera (SfMNPV) - 6NR to those two larvae species.

As for pupation, an inverse effect of the mortality was observed since the larvae that have not died have had the chance to develop and reach the pupal stage. Therefore, the $S$. frugiperda larvae presented a reduced pupation stage percentage, since the larvae mortality increased with the polyhedra concentration. The few surviving larvae reached the pupal stage. The same was observed for H. zea and D. saccharalis because mortality was low, enabling larvae survivors to reach the pupal stage. 
The innocuous effect on the three species tested in the second generation can be explained by the fact that in the parents the viruses failed to generate the infectious cycle. Thus, there was no toxicity and therefore nothing was transmitted to descendants in the second generation. It was therefore not possible to observe an effect on the second generation of larvae. The study of hemocytes is important to understand the interactions between hosts and entomopathogen, since knowledge of immune responses present in the hemolymph of insects can provide relevant information for the study of new forms of microbial pest control (Bovo et al., 2005).

In the sublethal effects, we observed a reduction in the number of egg masses was observed with increasing concentration of $B$. spodoptera polyhedra (SfNPV) 6NR. This result can be explained by the fact that mortality in the first generation was higher in $S$. frugiperda. Thus, a smaller number of larvae reached the adult stage, reproduced and oviposited, generating fewer egg masses. This result also demonstrates the negative effect of $B$. spodoptera (SfNPV) 6NR on the population growth rate of $S$. frugiperda. For $D$. saccharalis the number of egg masses was unaffected, remaining constant according to the number of surviving larvae. For $H$. zea, in turn, there was an increase in the number of egg masses.

Assays to detect and quantify $S$. frugiperda digestive enzyme profile, eg proteases, are essential to understand the susceptibility of this insect to B. spodoptera (NPV) 6NR. For an explanation of the selectivity to $S$. frugiperda found, it becomes necessary to carry out work which characterizes digestive enzymes (proteases) that comprise the digestive system of the assessed species of larvae. Thus, one could understand the control strategies undertaken in the intestine, its action in alkaline $\mathrm{pH}$, and possible resistance in each species (Marinho et al., 2008). Probably there are different digestive enzymes that interfere with the baculovirus action in the insect midgut. Furtheremore, is also necessary to characterize cell lines as being permissive or not, for viral replication.

Possibly the species $H$. zea and $D$. saccharalis lack the specific receptors necessary for the infective particles to entering the cells. They could also have the genes essential for DNA replication of the baculovirus or the required action sites. Therefore, gene sequencing could explain the selective action of B. spodoptera (SfMNPV) - 6 NR to the larvae.

Once it is highly specific, $B$. spodoptera (SfMNPV) - 6NR is a promising control agent to be used in the integrated management of that species in maize. Recombinant baculoviruses have been developed as a way to enhance the virulence of the baculovirus with the insertion of hormone genes and/ or proteases in the baculovirus genome against their hosts. The introduction of genes of keratin and ScathL protease in the of Autographa californica multicapsid nucleopolyhedrovirus baculovirus (AcMNPV) genome promote increasing of its virulence to $S$. frugiperda, showing a reduced death time (Maruniak, 1992). Therefore, this technique could be useful to increase an alternative to increase the bio-insecticidial properties of B. spodoptera (SfMNPV) - 6NR to $S$. frugiperda, a major pest in corn in Brazil.

\section{Conclusion}

The Baculovirus spodoptera (SfMNPV) 6NR is specific to Spodoptera frugiperda and is harmless to Helicoverpa zea and Diatraea saccharalis. 


\section{Acknowledgments}

To the Fundação de Amparo à Pesquisa de Minas Gerais (FAPEMIG) for financial support of the work.

\section{References}

ANDRADE, F. G.; NEGREIRO, M. C. C.; FALLEIROS, A. M. F. Aspectos dos mecanismos de defesa da lagarta da soja Anticarsia gemmatalis (hübner, 1818) relacionados ao controle biológico por Baculovirus anticarsia (agmnpv). Arquivos do Instituto Biológico, São Paulo, v. 71, n. 3, p. 391-398, jul./set. 2004.

BARRETO, M. R.; GUIMARÃES, C. T.; TEIXEIRA, F. F.; PAIVA, E.; VALICENTE, F. H. Efeitos de isolados do Baculovirus spodoptera em lagartas de Spodoptera frugiperda (J.E. Smith) (Lepidoptera: Noctuidae) e sua caracterização por meio de RAPD. Neotropical Entomology, Londrina, v. 34, n. 1, p. 67-75, jan./fev. 2005. DOI: 10.1590/S1519-566X2005000100010.

BOVO, F.; SOUZA, R. F.; SOZA-GOMEZ, D. R.; MOSCARDI, F.; PARO, F. E.; ITANO, E. N.; ONO, M. A. Produção de anticorpos policlonais para lectina de hemolinfa de Anticarsia gemmatalis. Semina: Ciências Biológicas e da Saúde, Londrina, v. 26, n. 1, p. 31-36, jan./ jun. 2005. DOI: 10.5433/1679-0367.2005v26n1p31.

CRAWLEY, M. J. The R book. West Sussex: John Wiley \& Sons, 2007. 942 p. DOI: 10.1002/9780470515075.

FIGUEIREDO, M. L. C.; MARTINS-DIAS, A. M. P.; CRUZ, I. Relação entre a lagarta-do-cartucho e seus agentes de controle biológico natural na produção de milho. Pesquisa Agropecuária Brasileira, Brasília, DF, v. 41, n. 12, p. 1693-1698, dez. 2006.

DOI: 10.1590/S0100-204X2006001200002.

GREENE, G. L.; LEPPLA, N. C.; DICKERSON, W. A. Velvetbean caterpillar: a rearing procedure and artificial medium. Journal of Economic Entomology, Lanham, v. 69, n. 4, p. 487-488, 1976.

DOI: $10.1093 /$ jee/69.4.487.

HENSLEY, S. D.; HAMMOND, A. H. Laboratory techniques for rearing the sugarcane borer on an artificial diet. Journal Economic Entomology, Lanham, v. 61, n. 6, p. 1742-1743, dez. 1968. DOI: 10.1093/jee/61.6.1742.

LUIZ, C. B. F.; MAGRO, S. R. Controle biológico das pragas da espiga, sobre parâmetros qualitativos e quantitativos na cultura do milho de safrinha em Ubiratã/ PR. Campo Digital, Campo Mourão, v. 2, n. 1, p. 13-21, jan./jun. 2007.

MARINHO, J. S.; OLIVEIRA, M. G. A.; GUEDES, R. N. C.; PALLINI, A.; OLIVEIRA, C. L. Inibidores de proteases de hospedeiros nativos e exóticos e sua ação em intestinos de lagartas de Thyrinteina leucoceraea. Revista Árvore, Viçosa, MG, v. 32, n. 6, p. 1125-1132, ago. 2008. DOI: $10.1590 / \mathrm{S} 0100-67622008000600018$.

MARUNIAK, J. E. Contribuição da biologia molecular para o melhoramento de vírus de insetos como produtos de controle biológico. Pesquisa Agropecuária Brasileira, Brasília, DF, v. 27, p. 143-150, abr. 1992.

OECD. Organisation for Economic Co-operation and Development.Consensusdocumentoninformation usedin the assessement of environmental applications involving Baculovirus. Paris, 2002. 90 p. (Series on Harmonization of Regulatory Oversight in Biotechnology, n. 20).

OLIVEIRA, A. M.; MARACAJÁ, P. B.; DINIZ FILHO, E. T.; LINHARES, P. C. F. Controle biológico de pragas em cultivos comerciais como alternativa ao uso de agrotóxicos. Revista Verde, Mossoró, v. 1, n. 2, p. 1-9 jul./dez. 2006.

PARRA, J. R. P. Técnicas de criação de insetos para programas de controle biológico. 3. ed. Piracicaba: FEALQ, 1996. 137p.

R DEVELOPMENT CORE TEAM. R: a language and environment for statistical computing. Vienna: $\mathrm{R}$ Foundation for Statistical Computing, 2011. 
SANTOS, V. M. R.; DONNICI, C. L.; COSTA, J. B. N. da; CAIXEIRO, J. M. R. Compostos organofosforados pentavalentes: histórico, métodos sintéticos de preparação e aplicações como inseticidas e agentes antitumorais. Química Nova, São Paulo, v. 30, n. 1, p. 159-170, nov. 2007. DOI: 10.1590/S0100-40422007000100028.

VALICENTE, F. H.; TUELHER, E. de S. Controle biológico da lagarta do cartucho, Spodoptera frugiperda, com baculovírus. Sete Lagoas: Embrapa Milho e Sorgo, 2009. 14 p. (Embrapa Milho e Sorgo. Circular Técnica, 114).
VIEIRA, C. M.; TUELHER, E. S.; VALICENTE, F. H.; WOLFF, J. L. C. Characterization of a Spodoptera frugiperda multiple nucleopolyhedrovirus isolate that does not liquefy the integument of infected larvae. Journal of Invertebrate Pathology, San Diego, v. 111, n. 2, p. 189192, 2012. DOI: 10.1016/j.jip.2012.07.010.

YAMAMOTO, T.; TANADA, Y. Biochemical properties of viral envelopes of insect baculoviruses and their role in infectivity. Journal of Invertebrate Pathology, San Diego, v. 32, n. 2, p. 202-211, 1978.

DOI: 10.1016/0022-2011(78)90031-9. 